\title{
Snow Cover and Spring Flood Flow in the Northern Part of Western Siberia (the Poluy, Nadym, Pur, and Taz Rivers)
}

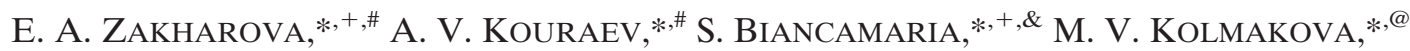 \\ N. M. Mognard, ${ }^{*}, \&$ V. A. Zemtsov, ${ }^{@}$ S. N. Kirpotin, ${ }^{@}$ And B. Decharme** \\ * UPS (OMP-PCA), LEGOS, Université de Toulouse, Toulouse, France \\ ${ }^{+}$CNRS, LEGOS, Toulouse, France \\ \# St. Petersburg Branch, State Oceanography Institute, St. Petersburg, Russia \\ @ Tomsk State University, Tomsk, Russia \\ \& CNES, LEGOS, Toulouse, France \\ ** GAME-Centre National de Recherche Météorologique, Toulouse, France
}

(Manuscript received 11 February 2011, in final form 6 May 2011)

\begin{abstract}
The paper aims to quantitatively estimate the role of snowmelt in the spring flood flow and the redistribution of river runoff for the northern (Arctic) part of the western Siberian Plain (the rivers Poluy, Nadym, Pur, and Taz). In this region, the presence of wetlands and thermokarst lakes significantly influences the seasonal redistribution of river discharge. First the study region is described, and the snow regime from in situ observations at the Tarko-Sale meteorological station is analyzed. As Special Sensor Microwave Imager (SSM/I) estimates of snow depth for this region are lower than in situ observations, a correction of the SSM/I snow depth estimates is done using snow parameters measured on the snow transect near the meteorological station Tarko-Sale for 1991-96. This reestimated snow depth is then used to assess the volume of water stored every winter on the watersheds for 1989-2006. This snow product is compared with the spring flood streamflow estimated from in situ observations, and the regional relationship between the snow water storage and flood flow is constructed. The proportion of meltwater that does not reach the main rivers and is thus evaporated or stored by the wetlands is estimated to be on average $30 \%$ (varying from $0 \%$ to $74 \%$ ). We observe an increasing trend of this value from $20 \%-30 \%$ in the early 1990 s to $50 \%-60 \%$ in the mid-2000s. This increase could be attributed to several factors such as increased air temperature (leading to increased evaporation, changes in vegetation cover, and active layer depth) and also to human activity.
\end{abstract}

\section{Introduction}

High-latitude terrestrial ecosystems respond to global climate changes through exchange of water, energy, and gases with the atmosphere and through freshwater input to the Arctic Ocean. Climatic changes are already affecting boreal river systems through rising air temperature and precipitation (Zakharova et al. 2009b), thawing of permafrost (Zhang et al. 2003), disappearing lakes (Smith et al. 2005), and increase in river runoff (Grippa et al. 2007; Déry et al. 2009; Yang et al. 2003). To improve our understanding of the processes and feedbacks involved, as well as the potential impact of climate variability

Corresponding author address: A. V. Kouraev, UPS (OMP-PCA), LEGOS, Université de Toulouse, 14 Av. Edouard Belin, F-31400 Toulouse, France.

E-mail: kouraev@legos.obs-mip.fr and human activity on the functioning of boreal watersheds, we need to estimate and quantify the role and contribution of various components of the water budget.

One of the key components of the water budget is the snow cover. Its contribution to the river outflow and its seasonal and interannual variability is very dynamic, and changes in snowmelt runoff will be one of the most pronounced hydrologic responses to climate change. The snow depth (SD) and snow water equivalent (SWE) are important for a number of applications and tools, including flood estimation and prediction and hydrological modeling. The existing network of terrestrial observations of snow cover parameters is sparse and often not able to represent well the processes on large and midsized watersheds (Shiklomanov et al. 2002). In this respect a very promising solution is to combine in situ data with satellite microwave remote sensing techniques. Satellite observations of spatial and temporal distribution 


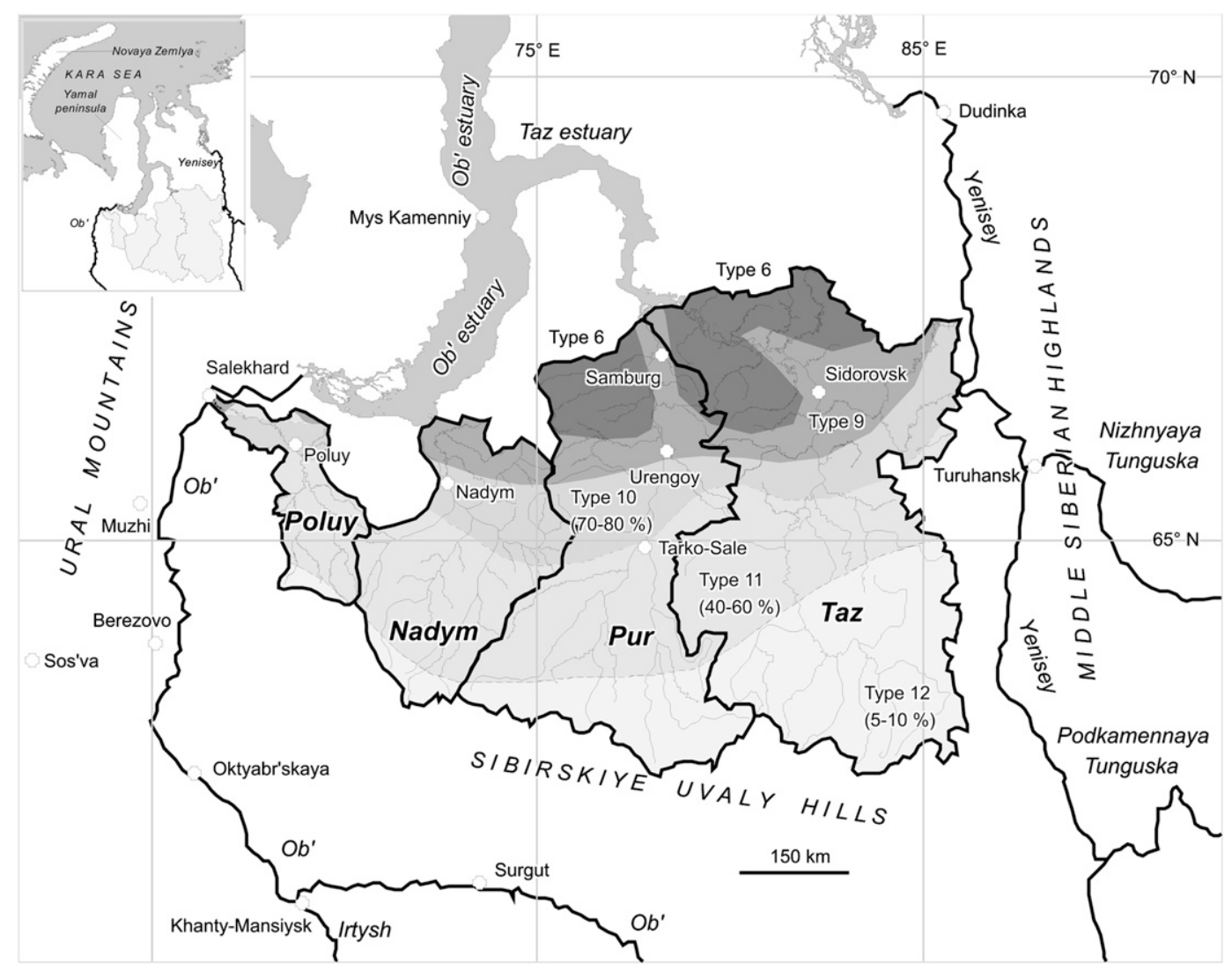

FIG. 1. Overview map of the northern western Siberia, showing watersheds and main streams for the Poluy, Nadym, Pur, and Taz River systems, as well as permafrost types (shades of gray; type labels are on map) after Kondratyev and Kudryavtsev (1981) (only types within the PNPT watershed are shown).

of various snowpack parameters, once calibrated with the in situ data, provide continuous, reliable, regular, and weather-independent data over large regions.

Western Siberia is a large flat region located between the Ural Mountains and the middle Siberian Highlands. Most of its territory comprises the watershed of the $\mathrm{Ob}$ ' River (almost 3 million $\mathrm{km}^{2}$ ); while its northern part contains the rivers Nadym, Pur, and Taz, as well as western tributaries of the Yenisey River (Fig. 1). The total annual runoff from western and eastern Siberia to the Kara Sea is $1250 \mathrm{~km}^{3} \mathrm{yr}^{-1}$. This is the maximal freshwater input among all other Arctic seas, and it dramatically affects the hydrology, hydrochemistry, and hydrobiology of the Arctic Ocean.

The presence of wetlands and numerous lakes in western Siberia results in a very high rate of evaporationhigher than for any other large Siberian watershed (Sokolov 1952). These natural objects also act as a temporary storage of water after the spring snowmelt, gradually releasing water in summer. These two factors significantly influence seasonal redistribution of river discharge.
The relationship between river discharge and snowmelt water for the $\mathrm{Ob}$ ' watershed has been addressed in several publications (Burakov 1978; Yang et al. 2003; Berezovskaya et al. 2004; Ye et al. 2004; Grippa et al. 2005, 2007; Papa et al. 2007). These authors have analyzed the relationship between the Ob' River discharge (measured at the outlet station Salekhard) and various environmental parameters from in situ observation network and remote sensing observations. These parameters include snow depth, snow extent, snowmelt timing, inundated zones extent, air temperature, and precipitation. They stress the importance of evapotranspiration (ET) in the Ob' River watershed that is related to various factors (high percentage of ponds and wetlands, vegetation conditions, lower spatial extent of permafrost, etc.).

In this work we look at the northern part of the western Siberian Plain [the rivers Poluy, Nadym, Pur, and Taz (PNPT)]. Compared to the large watersheds of rivers such as the Ob' and Yenisey, which span at least two different vegetation and climatic zones, PNPT rivers can be considered a relatively homogeneous region for 
their natural conditions, the influence of permafrost, wetland coverage, and topography.

By using values with high temporal resolution (such as daily values of discharge and meteorological parameters) we aim at estimating the influence of the wetlands on the volume of snowmelt water and thus the seasonal distribution of PNPT rivers discharge. This is a continuation of previous work (Zakharova et al. 2009a) where we have estimated annual input from spring snowmelt, base flow, and interflow-overland flow by a quantification of river runoff using a graphical hydrograph separation approach (see section 4a).

In the previous study we have verified the consistency of snow estimates from various datasets [from in situ stake observations of snow accumulation at Oktyabr'skaya station, National Centers for Environmental Prediction (NCEP) reanalysis, and Special Sensor Microwave Imager (SSM/I)] for establishing the relationship with the volume of spring meltwater. We have found that among the datasets tested, the SSM/I estimates retrieved by the dynamic algorithm (Grippa et al. 2004, 2005; Biancamaria et al. 2008) better explain the interannual variability of the spring flood river output. Compared to stations, the satellite snow product accounts for the spatial distribution of snow cover over the watershed. It also takes into account temporal transformation of snow (grain size change, sublimation, and wind redistribution) as compared to the reanalysis dataset, where snow is usually calculated as precipitation during the winter, and which is based on data from a network of meteorological stations that are rather sparse in the Arctic region.

We have also estimated the extent of wet zones using radar altimetry data. By using a threshold value of Envisat radar altimeter (RA-2) backscatter, we have classified the observations with $20 \mathrm{~dB}$ as wet zones. The ratio of altimetric observations classified as wet zones to the total number of observations serves as an equivalent of wet zone area for each watershed. The definition of wet zones in our case denotes a multitude of objects that are either constant in time (rivers, lakes, wetlands, and proper wet zones) or have seasonal variability (flooded areas). We have noted that the bigger the wet zone area on the watershed, the weaker the relationship between snow storage and flood flow.

In this paper we concentrate on quantitative estimation of the role of snowmelt in the spring flood flow and the redistribution of river runoff. First we describe the study region (section 1). Then (section 2) we analyze the snow regime from in situ observations at the Tarko-Sale meteorological station and establish a relationship between SSM/I snow depth estimates and snow parameters measured on the meteorological station's snow transect. We use a product that takes into account the temporal and spatial variability of snow grain size derived from the estimation of the thermal gradient in the snowpack (Mognard and Josberger 2002). We use this relationship to assess the volume of water stored every winter on the watersheds and compare it with the spring meltwater flood volume for the four rivers (section 3 ). We quantify the part of meltwater that does not reach the main rivers and is thus evaporated or stored by the wetlands. We analyze its temporal variability and put it in the context of the changes in surface properties due to climate warming and human activity (section 4).

\section{Study area}

The Ob' and Yenisey have extensive and complicated river systems that span large watersheds located in various climatic zones (from steppes to tundra) and thus have different natural and hydrological regimes for their various parts. Smaller rivers in the northern part of western Siberia - the PNPT rivers (Fig. 1) — are characterized by more homogeneous natural conditions compared to the $\mathrm{Ob}^{\prime}$ and Yenisey Rivers. Here we refer to the fact that PNPT rivers share similar climatic and geomorphological conditions: the same atmospheric circulation, frozen postglacial sediments, presence of continuous or discontinuous permafrost, flat bog plateaus, and sparse foresttundra vegetation. This makes them a good proxy of climate variability of the Arctic part of western Siberia.

Originating on the northern slopes of the Sibirskiye Uvaly hills (altitude ranging from $170-200 \mathrm{~m}$ to 230 $280 \mathrm{~m}$ from west to east) PNPT rivers flow northward to the Ob' estuary. The Pur and Taz Rivers join in the Taz estuary, which is a branch of the Ob' estuary. The Nadym River flows directly to the southern part of the Ob' estuary and the Poluy joins the final stretch of the Ob' River near Salekhard just before the Ob' enters the estuary.

The PNPT watershed is about $345000 \mathrm{~km}^{2}$. Watershed size and mean annual discharge for each river increases west to east (Table 1). Poluy is the smallest river (watershed $18500 \mathrm{~km}^{2}$ and annual flow about $4 \mathrm{~km}^{3} \mathrm{yr}^{-1}$ ). The Nadym River has an intermediate position (watershed $64000 \mathrm{~km}^{2}$ and annual flow $12.5-14.6 \mathrm{~km}^{3} \mathrm{yr}^{-1}$ ). The Pur and Taz Rivers are twice as large as Nadym. The Taz is slightly bigger than the Pur, more in terms of watershed area (112000 km² for the Pur and $150000 \mathrm{~km}^{2}$ for the Taz) than of river flow $\left(25-28 \mathrm{~km}^{3} \mathrm{yr}^{-1}\right.$ for the Pur and 29-33 $\mathrm{km}^{3} \mathrm{yr}^{-1}$ for the Taz).

Most of the PNPT region has a moderate continental climate with short summers and cold and long winters. Mean annual temperature is $-9.3^{\circ} \mathrm{C}$ and average January air temperature is $-28^{\circ}$ to $-25^{\circ} \mathrm{C}$ (Ershov 1989). According to Kotlyakov (1997), the climatic number of days with stable negative air temperature ranges from 200 days in 
TABLE 1. Main characteristics of the PNPT rivers.

\begin{tabular}{|c|c|c|c|c|c|c|c|}
\hline \multirow[b]{2}{*}{ River } & \multirow{2}{*}{$\begin{array}{c}\text { Total watershed } \\
\qquad\left(\mathrm{km}^{2}\right)\end{array}$} & \multirow{2}{*}{$\begin{array}{c}\text { Measurement } \\
\text { station }\end{array}$} & \multirow{2}{*}{$\begin{array}{l}\text { Watershed at } \\
\text { station }\left(\mathrm{km}^{2}\right)\end{array}$} & \multirow{2}{*}{$\begin{array}{c}\text { Distance from } \\
\text { mouth }(\mathrm{km})\end{array}$} & \multicolumn{3}{|c|}{ Mean annual runoff $\left(\mathrm{km}^{3}\right)$ and observation period } \\
\hline & & & & & Source $1^{\mathrm{a}}$ & Source $2^{\mathrm{b}}$ & Source $3^{\mathrm{c}}$ \\
\hline Poluy & 18410 & Poluy & 15100 & 189 & $4.03(1948-68)$ & $3.9(1953-86)$ & $4.2(1953-99)$ \\
\hline Nadym & 64000 & Nadym & 48000 & 110 & $14.38(1955-57)$ & $12.57(1955-85)$ & $14.46(1955-91)$ \\
\hline Pur & 112000 & Samburg & 95100 & 86 & $28(1939-68)$ & $25.45(1939-85)$ & $28.25(1939-91)$ \\
\hline Pur & 112000 & Urengoy & 80400 & 245 & $23.8\left(1962,{ }^{\prime} 65\right.$, and '67) & & $23.99(1961-99)$ \\
\hline Taz & 150000 & Sidorovsk & 89100 & 357 & $33.42(1962-68)$ & $29.68(1952-65)$ & $32.99(1962-96)$ \\
\hline
\end{tabular}

${ }^{\text {a }}$ Vodogretskiy (1973).

${ }^{\mathrm{b}}$ Russian hydrometeorological database, cited after Akimenko et al. (2001).

${ }^{\mathrm{c}}$ Data from ArcticRIMS (2009).

the south to 240 days in the north of the watershed. The four rivers are ice covered for more than 7 months every year. The southernmost part of the watershed is located in the zone of northern taiga; the dominating vegetation cover here is the forest tundra. Purely tundra landscapes appear only in the lower reaches.

The PNPT rivers are located in the permafrost region (Fig. 1, Table 2). Permafrost is discontinuous (with 5\%$10 \%$ coverage) in the upper reaches; its percentage and thickness increase northward. In the lower reaches of the Nadym, Pur, and Taz the permafrost is continuous (soil temperatures of $-7^{\circ}$ to $-9^{\circ} \mathrm{C}$ and permafrost thickness of several hundred meters). The frozen ground is absent only under large rivers and lakes (more than $2 \mathrm{~m}$ deep) where taliks are formed. The taliks comprise the ground waters that support the winter discharge of the big rivers (Vodogretskiy 1973). Active layer (depth of seasonal thawing) for tundra landscapes typically ranges from $20-25 \mathrm{~cm}$ in the north to $80-90 \mathrm{~cm}$ in the south; for taiga zone it is up to $2 \mathrm{~m}$.

The PNPT watershed has mostly flat but intensely dissected relief with bogged interfluvial plains intersected by numerous small river valleys (Ershov 1989). About $35 \%-70 \%$ of PNPT watersheds is covered by wetlands and lakes (Zakharova et al. 2009a), with lakes representing less than 10\% (Vodogretsky 1973). According to our calculations based on maps provided in Ivanov and Novikov (1976), the bogs represent about $24 \%$ of the total watershed area for the Taz, $52 \%$ for the Pur and the Nadym, and $38 \%$ for Poluy.
The flat bogs prevail on the plateaus and on terrain with gentle slopes. These bogs consist of thick peat mounds (with active layer depth of 25-50 cm) alternated by linear depressions (active layer depth of about 80 $150 \mathrm{~cm}$ ). Because of the thermokarst processes, these depressions are interconnected and form the primary drainage network. The thermokarst activity also forms shallow ponds that can evolve to lakes and later to "khasyreys" (drained lakes) by drainage through the thermokarst hollows (Kirpotin et al. 2009). The fens are rare, but more abundant in the upper reaches of the PNPT rivers (in the zone of discontinuous permafrost) and on the bottom of the big valleys.

\section{Snow regime of the PNPT region from in situ and satellite estimates}

Snow cover in the PNPT region is the main contributor to annual flow. According to climatic estimates, total annual snowfall varies from more than $200 \mathrm{~mm}$ for southern parts of the Nadym, Pur, and Taz to 100 $200 \mathrm{~mm}$ for their northern parts and the Poluy watershed. The number of days with snowfall is 200-250 (Kotlyakov 1997).

Snowmelt water affects seasonal and interannual variability of river discharge. To understand the hydrological processes in this region we need correct estimates of water volume coming from snow based on in situ and satellite observations. In this section we first assess the snow regime from in situ observations at the Tarko-Sale

TABLE 2. Permafrost types after Kondratyev and Kudryavtsev (1981) covering the PNPT watershed.

\begin{tabular}{cccc}
\hline \hline Type & Percent of coverage $(\%)$ & Average temperature $\left({ }^{\circ} \mathrm{C}\right)$ & Depth of permafrost $(\mathrm{m})$ \\
\hline & 100 & Continuous permafrost & $300-500 \mathrm{~m}$ \\
6 & 100 & -7 to -9 & $100-300 \mathrm{~m}$ \\
& & -1 to -3 & up to $100 \mathrm{~m} ;$ rarely $200-300 \mathrm{~m}$ \\
10 & $70-80$ & Discontinuous permafrost & $50-70 \mathrm{~m}$; rarely $100-200 \mathrm{~m}$ \\
11 & $40-60$ & 0 to $-2 ;$ thaw soils: +1 to 0 & $15-20 \mathrm{~m}$; rarely up to $50 \mathrm{~m}$ \\
12 & $5-10$ & 0 to -1 ; thaw soils: +2 to 0 & 0 to $-0.5 ;$ thaw soils: +2 to 0 \\
\hline
\end{tabular}




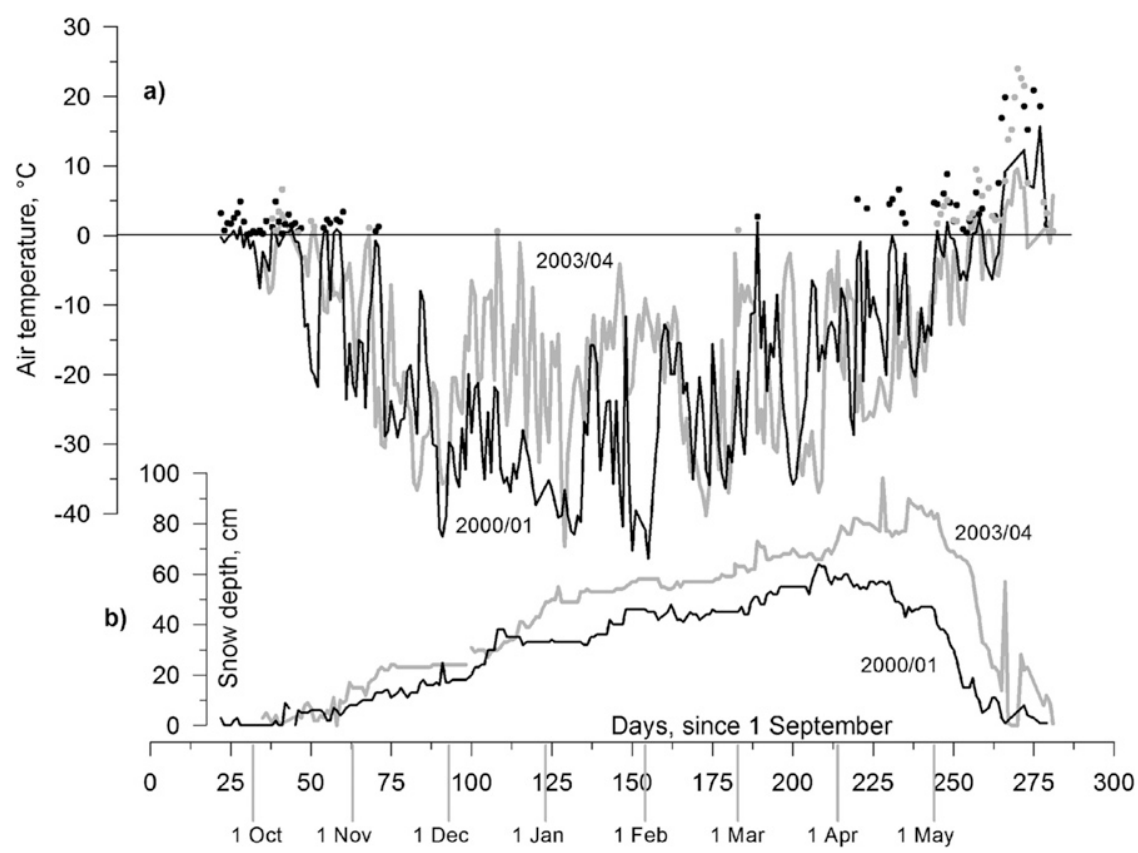

FIG. 2. Daily variations of (a) mean air temperature $\left({ }^{\circ} \mathrm{C}\right)$ and $(\mathrm{b})$ snow depth $(\mathrm{cm})$ at the Tarko-Sale meteorological station for selected winters with low (2000/01; black line) and high snow depth (2003/04; thick gray line). Maximal daily air temperatures $>0{ }^{\circ} \mathrm{C}$ are also plotted as black (2000/01) and gray (2003/04) dots.

meteorological station and then compare it to the passive microwave satellite estimates, establishing a sound relationship between these two datasets.

\section{a. In situ snow observations}

In the middle of the PNPT region there is one meteorological station-Tarko-Sale-that provides the synoptic information on meteorological parameters as well as the quasi-regular data on snow transects. This station is located at the confluence of the Pur and the Pyakupur Rivers at $64.923^{\circ} \mathrm{N}, 77.785^{\circ} \mathrm{E}$ (see Fig. 1).

Usually synoptic observations of snow depth at the meteorological stations are single-point measurements, done using a graduated stake installed at the station. However, Tarko-Sale is a part of the Russian meteorological network of stations with an enlarged program of observation, including "snow on transect" data. The transect is a line along which measurement of snow depth and snow density are made every several tens of meters. Usually such transect is up to several kilometers long and crosses the most representative landscape of the zone (sometimes there are two types of transectsone located in the forest and another one in the open field- to account for differences in snow accumulation). All collected data (about 100-200 snow depth points measurements and about 20 measuring points of integral snow density along the transect) are then averaged and provided as single mean values of snow depth and SWE for a given date.

For the Tarko-Sale station, measurements over a nearby snow transect in the open forest landscape (January 1991-December 1996) are available through a dataset "Historical data of the snow cover measurements from the Former Soviet Union Hydrological Snow Surveys" (Krenke 2004). These data include the snow depth and the snow water equivalent measurements, done once per month at the beginning of the snow season and once every 10 days starting in February. There are other meteorological stations from the above-mentioned dataset providing similar observations (Turukhansk, Mys Kamenniy, Surgut, Khanty-Mansiysk, Berezovo, Muzhi, and Sos'va; see Fig. 1). However, they are located several hundreds of kilometers from the PNPT watershed and often are representative for regions with significantly different geomorphologic conditions and, consequently, different snow accumulation regime.

According to in situ data, the first snow can appear as early as August, but the permanent snow cover is usually formed in October, when average daily air temperatures become negative (Fig. 2a). The accumulation goes on throughout the winter (Fig. 2b) with insignificant day-to day variations of snow depth. About $65 \%-95 \%$ of snow is already accumulated by the end of January. The maximal 


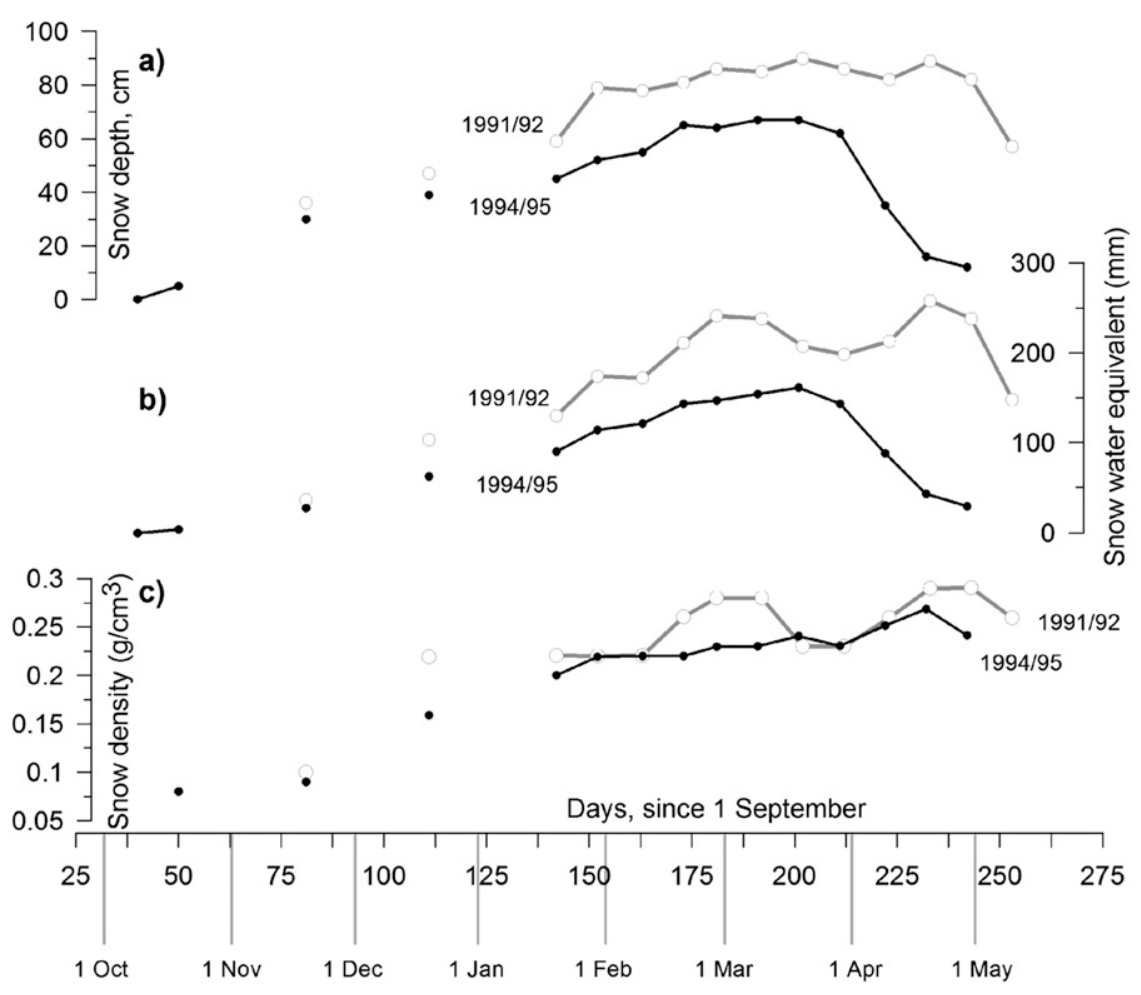

FIG. 3. Ten-day variations of (a) snow depth, (b) SWE, and (c) snow density at the forest transects near the Tarko-Sale meteorological station for selected winters with low (1994/95; black line with black circles) and high snow depth (1991/92; thick gray line with gray circles).

snow depth is observed in March-April (Figs. 2b and 3a) with winter maximal values of $67-107 \mathrm{~cm}$ for transect data and $64-98 \mathrm{~cm}$ for the data at the meteorological station stake.

After reaching maximal values, snow depth decreases when solar radiation increases and maximal daily air temperature become positive (see the temporal variability of the snow depth and positive maximal daily air temperatures; Fig. 2). Note that the mean daily air temperatures at this time are still negative. Increase in incoming heat leads either to direct snow sublimation to the atmosphere, or to snowmelt, evaporation, and compaction. The timing of the maximal snow water equivalent (values of 160-275 mm) corresponds to the maximal snow depth (Fig. 3b), but can have more significant variability during the winter because of snow metamorphism. Until the end of January the snow density at snow transect reaches on average $0.2 \mathrm{~g} \mathrm{~cm}^{-3}$. Just before the snowmelt onset in April, when the maximum water content in the snow is observed, snow density reaches $0.3 \pm 0.05-0.07 \mathrm{~g} \mathrm{~cm}^{-3}$. The timing and duration of snowmelt in spring varies from year to year, with early snowmelt observed in the first 10-day period of April and the late near the end of May (Fig. 3).

\section{b. Snow depth from the passive microwave satellite data and its relationship with in situ observations}

The meteorological data at the Tarko-Sale station provide useful and unique information but its application is limited to the local scale and is not adequate to assess snow cover parameters over the whole PNPT watershed. To overcome this limitation we use snow depth estimates from the passive microwave radiometer SSM/I on board the Defense Meteorological Satellite Program (DMSP) series, which has measured the earth brightness temperature at 19.35, 22.235, 37, and $85.5 \mathrm{GHz}$ for both horizontal and vertical polarization since 1987. The National Snow and Ice Data Center (NSIDC) provides the SSM/I data mapped onto an Equal-Area Scalable Earth Grid (EASE-Grid) projection with $628.3-\mathrm{km}^{2}$ spatial resolution (Armstrong et al. 2003). The initial data were averaged to obtain pentad (5-day) mean values to provide continuous spatial coverage.

A dynamic algorithm that takes into account temporal evolution of the snow grain size, developed by Mognard and Josberger (2002), has been used to retrieve snow depth from the SSM/I data. The inputs for the snow depth algorithm are 1) the difference between 19.35- and 37-GHz brightness temperature in horizontal polarization 
from SSM/I, 2) the air-snow interface temperatures from the National Centers for Environmental Prediction global reanalysis (Kalnay et al. 1996), and 3) the snow-ground interface temperatures modeled with the Interactions between Soil-Biosphere-Atmosphere (ISBA) scheme forced by the Global Soil Wetness Project Phase $2 \mathrm{P} 3$ precipitation field (Boone et al. 2006). Biancamaria et al. (2008) have validated a multiyear (1988-95) averaged SSM/I snow depth field for the high-latitude regions. The interannual variability of this snow product has been analyzed over the Ob' River basin (Grippa et al. 2004) and compared with discharge measurements at the $\mathrm{Ob}$ ' estuary (Grippa et al. 2005).

The SSM/I snow depth estimates from the dynamical algorithm for the Poluy, Nadym, Pur, and Taz Rivers have been analyzed for 1989-2006. At the end of January the satellite-derived snow depth reaches maximum values of $30-40 \mathrm{~cm}$. This is consistent with the synoptic observations at the Tarko-Sale meteorological station, but snow depth at transects is about $20-30 \mathrm{~cm}$ higher. Snow transect measurements are usually considered to give the most correct information about snow cover, because they average several tens of measurements and their location is chosen to represent well a given catchment. Starting in February, the SSM/I snow depth estimates start to vary considerably, while the in situ observations show gradual increase with low temporal variation.

To rectify this inconsistency we establish a regional relationship (Fig. 4) between snow depth measurements at Tarko-Sale transect (the only station providing such data for the PNPT watershed) and SSM/I estimates. For $\mathrm{SSM} / \mathrm{I}$ estimates, in order to reduce the potential errors (e.g., when a significant part of one specific EASE-Grid pixel covers the bottom of a large river valley), we use an average value for the four adjacent EASE-Grid pixels corresponding to the Tarko-Sale location. According to the global land cover map at 300-m resolution of the European Space Agency (ESA) GlobCover project, these four pixels contain $54.8 \%$ of open $(15 \%-40 \%$ density) forest- $43.6 \%$ classified as sparse vegetationgrassland on regularly flooded or waterlogged soil (while no specific distinction for boreal bogs are made there, these classes are apparently more or less equivalent to bogs) and $1.6 \%$ water bodies.

We compare the mean snow depth transect values for a given date with the SSM/I snow depth for a given corresponding pentad. This relationship is established for the period 1991-96 when the data from transects are available. The relationship is expressed as

$$
\mathrm{SD}_{\text {transect }}=1.67 \times \mathrm{SD}_{\mathrm{SSM} / \mathrm{I}}+23.10
$$

where SD is snow depth, with $r=0.73, p$ value $3 \times 10^{-10}$, and rmse $18 \mathrm{~cm}$.

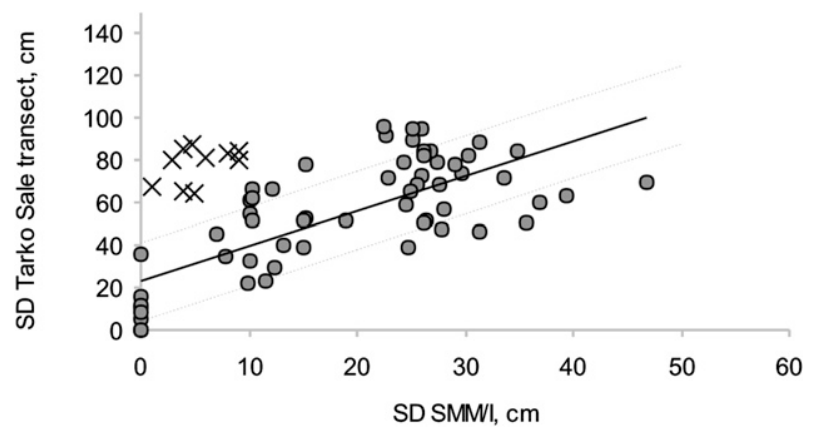

FIG. 4. Relationship between 5-day-based SSM/I SD $(\mathrm{cm})$ for the period 1992-96 and 10-day snow depths from in situ snow transect measurements at the Tarko-Sale station. The linear relationship is given by the equation $\mathrm{SD}_{\text {transect }}=1.67 \times \mathrm{SD}_{\mathrm{SSM} / \mathrm{I}}+23.10$ (correlation coefficient $R=0.73$ ) and the gray lines show the 0.05 confidence interval. Crosses: observations excluded from the dataset when establishing the relation.

Using Eq. (1), we obtain new recalculated SSM/I snow depth estimates that are closer to in situ absolute values. Starting in February, the dynamic algorithm is often influenced by air temperature changes (related to the anticyclonic atmospheric circulation) providing too low snow depth values. As air temperature goes down from $-25^{\circ} \mathrm{C}$ to $-30^{\circ} \mathrm{C}$, strong vertical temperature gradient is established in the snowpack, leading to snow grain metamorphosis and reduction of snow density (Fig. 3b; 1991/92). The average snow depth on the snow courses is not very sensitive to this process (Fig. 3a). As the dynamic algorithm uses the temperature gradient between air and ground as a proxy for snow grain growth, for the very low air temperature it estimates very low snow depth (down to $0 \mathrm{~cm}$ ), which has not been observed either at meteorological stations stakes or at the snow transects. These correspond to the observations grouped in the cluster (Fig. 4) of high in situ and low SSM/I snow depth. Such low SSM/I values have been excluded from the analysis using threshold values (less than $10 \mathrm{~cm}$ for $\mathrm{SSM} / \mathrm{I}$ and more than $60 \mathrm{~cm}$ in situ snow depth). The stability of our relationship is proven by a leave-one-out test that gives mean error $0.20 \mathrm{~cm}$ and standard deviation of errors $19.1 \mathrm{~cm}$.

We did an additional test for the relationship between the SSM/I product and in situ measurements on snow transects for the two closest hydrometeorological stations (Muzhi and Sos'va) located almost at the same latitude but 600 and $800 \mathrm{~km}$ westward, correspondingly. The Muzhi station is situated on the left bank of the Small Ob' River, while Sos'va is midway between the Ob' River and the Ural Mountains. The analysis of the relationship between 1) snow depths on transects and 2) average snow depth for four SSM/I pixels corresponding to each station allows us to say that the correlation established 
for Tarko-Sale characterizes well the situation for the region between Tarko-Sale and Muzhi. While the slope of the relationship is lower and the intercept are smaller toward the Ural Mountains (correlation coefficients 0.63 and $0.67, p$ values of $1 \times 10^{-8}$ and $1 \times 10^{-9}$, rmses of 18 and $16 \mathrm{~cm}$, slopes of 1.2 and 1.28 , and intercepts of 24.6 and 12.1 for Muzhi and Sos'va, respectively), most points for Muzhi are within the $5 \%$ confidence interval of the relationship established for the TarkoSale. As natural conditions (relief, vegetation cover, and climate) do not change much eastward until the Yenisey River, we assume that the relationship established for Tarko-Sale is valid also for the eastern part of the PNPT watershed.

\section{Flood flow and its relationship with the snowmelt water}

Quantification is necessary to identify the complex linkages and feedback processes between snowmelt and river flood flow. Most studies (Yang et al. 2003; Berezovskaya et al. 2004; Ye et al. 2004; Grippa et al. 2005, 2007; Papa et al. 2007) have used monthly or annual average values of river discharge, snow cover, and other meteorological parameters to analyze the hydrological cycle. However, for more accurate estimation of relationship between runoff parameters and responsible factors we need to look at the spring flood as one continuous physical process. Spring flood can start and end at different dates and its duration may vary significantly from one year to another, and thus some of the interannual variability of snowmelt is hidden when monthly or annual averages are used. In the following section we compare the flood flow volume from in situ daily discharge data (one value per year per watershed) with the satellite estimates of the snow depth (one value per year per watershed) during each winter (before the melt starts). The flood flow was calculated as the volume of water that passes during the flood period. The length of the flood period varies from year to year and was determined for each year and each watershed individually. This approach allows us to quantify the role of the catchment's water storage and release in spring flood flow generation.

\section{a. Flood flow from in situ discharge data}

For the PNPT rivers about $50 \%$ of the annual water flux passes during the spring flood observed in MayJune (Burakov 1978; Zakharova et al. 2009a). The spring flood average duration ranges from 50 days (for Poluy) to 100 days (for Taz) and depends on the size of the watershed. The maximal flood discharge value is about
7 times higher than the mean annual discharge for the Poluy, Nadym, and Pur Rivers and 3.5 times for the Taz.

An important feature of the western Siberian Arctic (affected by permafrost) is that water from the bogged areas (occupying 35\%-70\% of watersheds) drains out mainly through wet depressions and hollows. During the spring flood, meltwater runs from the mounds into the depressions where it forms chains of ponds separated by snow dams. The destruction of these dams depends on the topography, as well as on the yearly snow conditions and heat flux rate. If the breakup of snow dams starts from the upper reaches of the drainage network, then the propagation of the surface runoff wave breaks up these dams, the flood wave rises very rapidly, and the maximal discharges are high. On the contrary, if the snow dam breakup starts from the lower reaches without much mechanical forcing, then the water is released more gradually and the peak discharges are usually low during these years (Novikov 1988).

Another feature of the spring flood on the permafrostaffected watersheds is that the flood flow comes mainly from the snowpack of the current winter. The part of the water stored earlier (during the autumn of the previous year) in the active layer does not play an important role, because during the most part of the flooding period the active layer is still frozen at these latitudes (Woo et al. 2008) and the autumn water storage in the watershed is usually high and constant (Moskvin 1989; Burakov 1978).

The amount of water coming to the river throughout a year is originated from three main sources: snow meltwater, rain, and groundwater. To assess the hydrological processes for each watershed we have quantified the input of each of these sources for each of the four rivers (Zakharova et al. 2009a). This quantification has been done by a method of graphical hydrograph separation using daily discharge values at the gauging stations [data from Regional, Integrated Hydrological Monitoring System for the Pan-Arctic Land Mass (ArcticRIMS)]. This method gives good, representative results for arctic conditions (McNamara et al. 1997). An example of the annual hydrograph and its separation is presented in Fig. 5.

The spring flood related to snowmelt is very pronounced for Arctic rivers and is characterized by rapid rise of discharge and high peak. To estimate the water flux originated from the melting snow and passing during the spring flood, we performed a recession analysis for each river. We have also cut the intermediate rain peaks at the recession limb of the hydrograph and then deducted the base flow (the deep ground waters) calculated by interpolation between lowest winter discharges of adjacent years (see Fig. 5, line A-B). Base flow is formed by water from deep aquifers. It has a quasiconstant discharge throughout the year and can be 


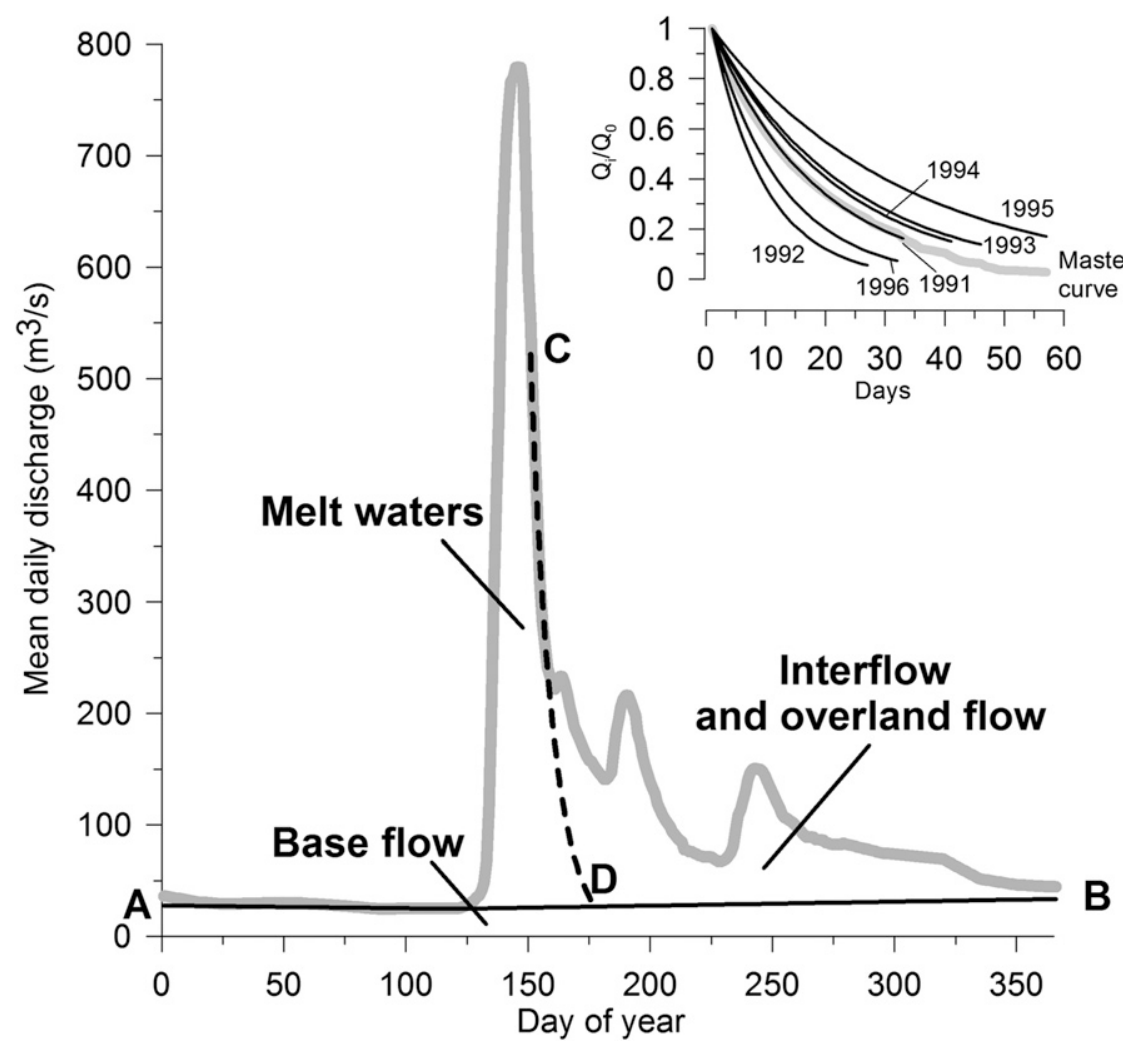

FIG. 5. Example of hydrograph separation for Poluy in 1992. Thick gray line: mean daily discharge, black line (A-B): base flow, and black dotted line (C-D): recession curve. Insert on upper right: an example of recession (1991-96; black lines) and master (thick gray line) curves for the Poluy.

estimated during the drought (or ice covered) periods by an interpolation between the lowest discharge values at the autumn or winter (Sokolovskiy 1968; Maidment 1993). For the Nadym River the base flow is calculated using the historical (1978-88) winter discharges, and as for the modern period the observations on the winter discharges are not complete. Part of the meltwater infiltrates at the end of the spring season in the soil and reaches the river channels after the end of the main flood. In the PNPT region the part of the percolating waters is relatively low because soil is still frozen during the whole melt period. However, we made an attempt to estimate and include this part into the flood flux using a recession curve. The recession curve is approximated by an exponential relationship (Maidment 1993) (see Fig. 5, line C-D):

$$
Q_{i}=\alpha \exp \left(\beta Q_{0}\right)
$$

where $Q_{i}$ is the water discharge for a given day from the start of flood and $Q_{0}$ is the maximal discharge for the year.

We have constructed the recession curves for each river for each year starting from the last 5-10 days of the flood end. Then we normalized the recession curve by the maximal value of discharge and averaged the ordinates of the normalized curves. Then this average recession curve (specific for each river) was applied to each year. Values of flood flow were thus obtained for 1991-96 for Poluy, 2000-08 for Nadym, 1992-2008 for Pur, and 1989-96 for Taz (Zakharova et al. 2009a). As recession behavior for a stream can change from flood to flood (influence of small rainfall, variations in catchment, and bank storage capacity), application of the average recession curve provides a uniform method for graphical separation and allows us to reduce subjective errors. We estimate that for the PNPT rivers the potential uncertainties related to the application of an average recession curve instead of an individual one are $\pm 5 \%$ of the flood flow value.

\section{b. Relationship between satellite snow water equivalent estimates and flood flow}

To obtain the SWE on the river watersheds prior to snowmelt, we use the adjusted average SSM/I snow depth estimates (section 3b) for March. To convert these to SWE, the values should be multiplied by the snow 


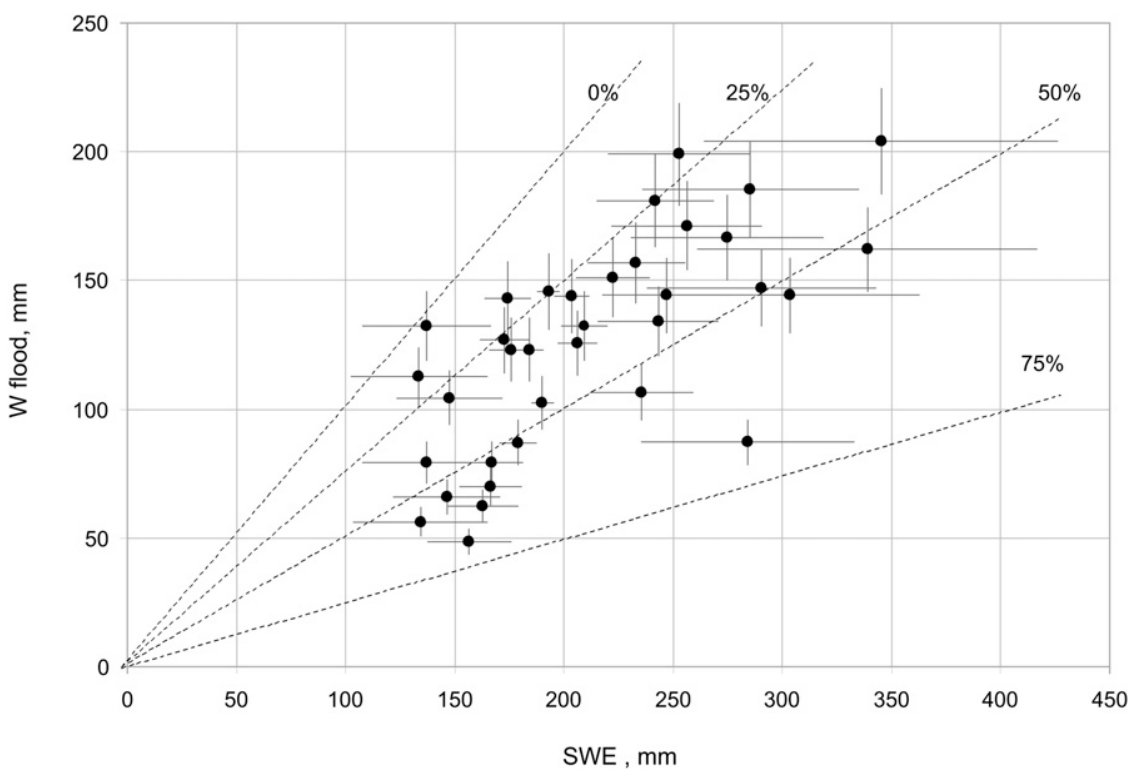

FIG. 6. Relationship of average SWE ( $\mathrm{mm}$ ) calculated from SSM/I data and flood flow ( $W$; in $\mathrm{mm}$ ) estimated from in situ daily discharge values for the PNPT rivers. The linear relationship is described by the equation $W_{\text {flood }}=0.53 \mathrm{SWE}+22.66$ (correlation coefficient $R=0.70$ ). Dashed lines: theoretical lines for $0 \%, 25 \%, 50 \%$, and $75 \%$ loss of meltwater.

density. Tarko-Sale in situ data for 1991-96 show that during the snowmelt the mean snow density is $0.30 \pm$ $0.07 \mathrm{~g} \mathrm{~cm}^{-3}$. As we have no in situ snow density values for the whole period of SSM/I data, an average value of $0.30 \mathrm{~g} \mathrm{~cm}^{-3}$ has been used for all years. A variability of $\pm 0.07 \mathrm{~g} \mathrm{~cm}^{-3}$ in snow density leads on average to a variability of $\pm 8 \mathrm{~mm}$ in SWE estimates. Similar averages and standard deviations for snow density were found for other stations with a tendency of snow to be little dryer in southern and western areas (0.29 and $0.28 \mathrm{~g} \mathrm{~cm}^{-3}$, correspondingly).

By comparing these SWE values to flood flow estimates (see section $4 a$ ) we observe a significant relationship (with linear correlation coefficient $R=0.70$, $p$ value $3 \times 10^{-6}$, and rmse $29 \mathrm{~mm}$ ) for the four PNPT rivers (Fig. 6). The amount of snow stored on the watershed before the melt season is proportional to the volume of water entering the river during the spring flood. However, a large portion of the potentially available water does not actually reach the rivers during the flood. This water is stored on the watershed in the active layer and in the permanent wetlands, where it evaporates or drains out gradually to the rivers during the summer, supporting elevated summer discharges. Simulations of runoff from two Canadian Arctic watersheds (Putuligayuk and Kuparuk Rivers, Prudhoe Bay, Alaska) indicate that on average $37 \%$ of snow meltwater goes into storage each year and does not contribute to streamflow (Bowling and Lettenmaier 2010). Interannual variability of this value is high and varies from $4 \%$ to $80 \%$. Our calculations for the PNPT region show that this loss (calculated as the difference between the SWE values and flood flow estimates; see Fig. 6) is on average $30 \%$ (varying from $0 \%$ to $74 \%$ ). This is in good agreement with the estimates for the Canadian watersheds located in similar climatic conditions.

The evaporation in the PNPT region is relatively high because of the long sunshine duration and large wetland extent. To quantify the evaporation, estimation from the ISBA-Total Runoff Integrating Pathways (TRIP) global flooding model is used. This model was intensively validated using in situ discharge observations and satellitebased wetland extent estimates (Decharme et al. 2008, 2011). It was run in offline mode using an accurate atmospheric forcing from Princeton University (Sheffield et al. 2006) and using the monthly Global Precipitation Climatology Centre (GPCC) precipitation dataset. According to the ISBA-TRIP simulations for the PNPT watersheds the maximal evaporation is observed in JuneJuly. This is in good agreement with the estimations made by Ivanov and Novikov (1976) for the neighboring watersheds to the south. An average value of the deficit of precipitation minus evaporation for June-July for 19892006 is $26 \mathrm{~mm}$ (absolute values vary from 16 to $40 \mathrm{~mm}$ for different watersheds and different years; see Fig. 7c). Using SSM/I snow data and in situ discharge values we estimate that average meltwater loss for PNPT for $1989-2006$ is $60 \mathrm{~mm}$. About half of this loss $(26 \mathrm{~mm})$ is 


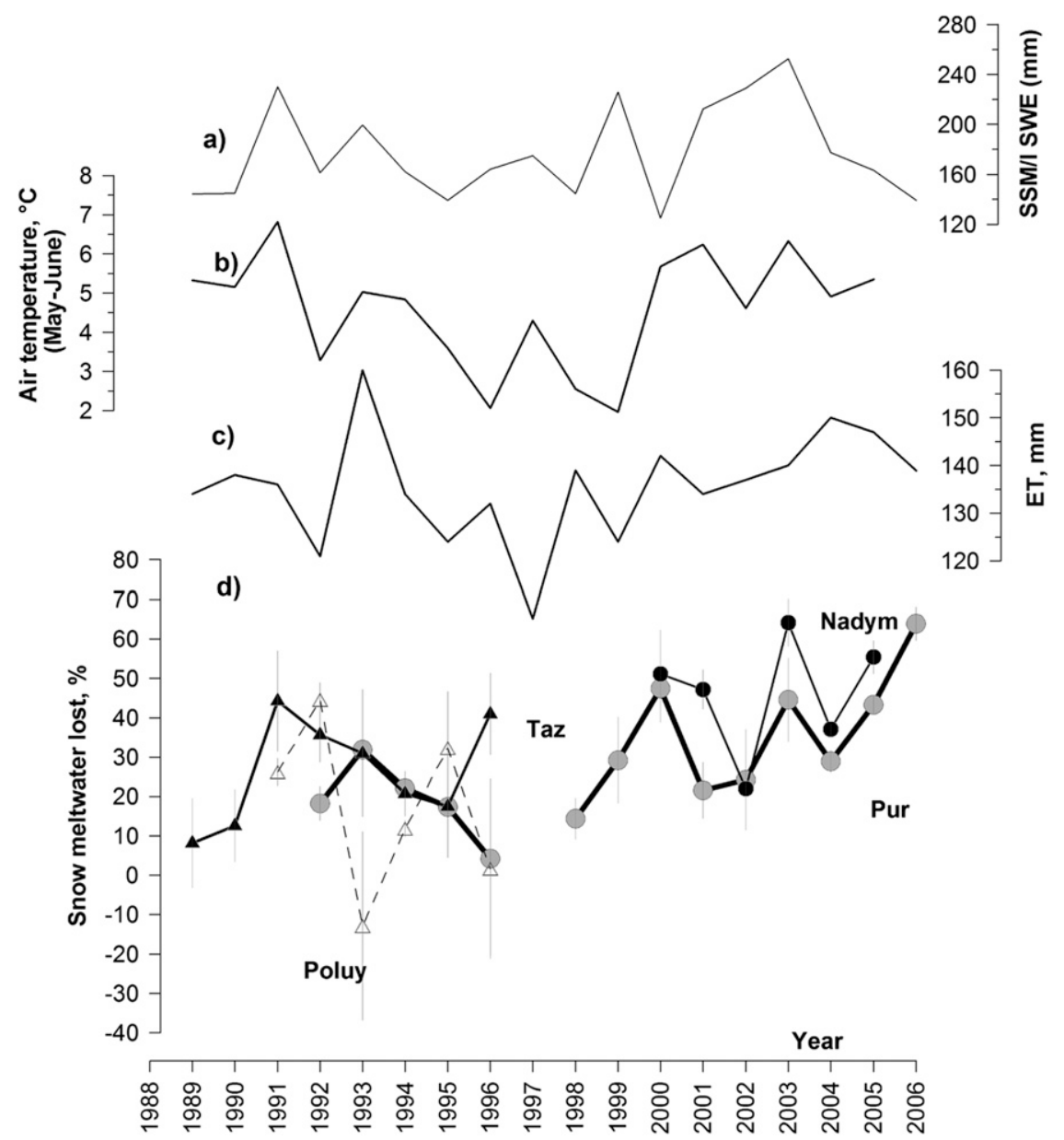

FIG. 7. Yearly values for 1989-2006 of the (a) SSM/I SWE (mm) in March; (b) air temperature $\left({ }^{\circ} \mathrm{C}\right)$ in May-June, average value for all PNPT watershed, NCEP reanalysis data from ArcticRIMS (2009); (c) ET (mm) from ISBA-TRIP simulations; and (d) portion of snowmelt water lost (in \% to the total amount of water stored in snow cover for each year). Thick black line with circles: the Pur, black line with circles: the Nadym, black line with triangles: the Taz, and dotted line with diamonds: the Poluy. Vertical gray lines: error bars.

discharged through evaporation from the wetlands and compensates the summer deficit of precipitation. The other $34 \mathrm{~mm}$ are stored in the watershed and then contribute to river runoff and recharge of the ground waters during summer.

\section{Discussion}

By analyzing the temporal variability of meltwater losses (difference between the SSM/I SWE estimates and flood flow runoff) we observe (Fig. 7) a positive trend over the PNPT river watersheds, with values rising from $20 \%-30 \%$ in the beginning of the 1990 s to $50 \%-$ $60 \%$ in the mid-2000s. Though the periods when the data are available differ (the Pur has the longest time span), there is a general year-to-year agreement between values for the three largest rivers-the Nadym, Pur, and Taz.

For the Poluy, we observe a particular interannual variability, most probably related to the surface properties. River Poluy is the smallest PNPT river with the lowest wetland and lake coverage of the watershed, so interannual changes in autumn storage are expected to be more variable compared to adjacent rivers, and play a more important role in flood generation. One value is negative (1993) - this could be related either to erroneous SSM/I estimates or to significant storage of water from the previous autumn in the soil and wetlands, which was then made available during spring melt and thus contributed to high river flood flow. The spring of 1993 was late and the melt was very intense. It provided high peak discharges in all rivers of the region. It is 
possible that for the Poluy the combination of specific weather conditions also resulted in earlier melting of the active layer. Water stock in the soil and wetlands was thus involved in the generation of flood runoff.

There could be several reasons for the general increasing trend of the meltwater loss in the PNPT watersheds. Time series of the SSM/I snow water equivalent, air temperature, and June-July evapotranspiration show large interannual variability (Figs. $7 \mathrm{a}-\mathrm{c}$ ) with no statistically significant temporal trends. While in general, changes in air temperature, evapotranspiration, and meltwater loss have similar tendencies, detailed year-by-year comparison of these values (not shown) indicates the complexity of the processes involved. Nevertheless, the evaporation seems to be the most important factor explaining the losses between water stored in the snow cover and water actually coming as flood flow.

However, there are several other issues to be considered. One is related to changes in watershed surface properties that affect the processes of water transmission through thermokarst hollows, mounds, and lakes. Rising air temperature at high latitudes lead to changes in the vegetation cover, which is one of the primary factors involved in generation of surface water flux. Because of the air temperature increase and the deepening of the active layer, a northward advance of the forest species has been observed in the PNPT region (Dr. N. P. Kosykh, Institute of Soil Sciences and Agrochemistry, 2008, personal communication).

The natural landscapes in the central part of the PNPT region (Nadym and partly Pur watersheds) have significantly changed during the last two decades because of intensive gas exploration. This human activity affects mainly the primary hydrological network. As this region is flat and swamped, surface drains form over long time periods by thawing through the thermokarst mounds. Gradually the wet hollows in the wetlands connect, providing semichannelled water movement down to the rivers. Construction of roads, electric lines, and gas pipelines lead to land use changes in wide lateral bands several kilometers wide. The use of all-terrain tractor-like vehicles mechanically disturbs the land and favors formation of new primary drain networks. Increased drainage of small ponds and lakes in the Arctic regions (Kirpotin et al. 2008) can be caused not only by the climate change but also (probably at the same scale) by human activity.

In Zakharova et al. (2009a) we note that among the four PNPT watersheds only for the Nadym River do we observe changes in the seasonal redistribution of stream flow as compared with estimates made for 1965-75 (Vodogretsky 1973). Other PNPT watersheds, located in the same climate and natural conditions, did not express any significant seasonal changes in regime. We suggest that this is related to human activity, because in the 1980s large and intensive gas exploration had started in the Nadym region.

Another issue is tundra fires. For forested landscapes, fires lead to increased peak flows observed soon after the events (Benavides-Solorio and MacDonald 2001). But the effect of fires in the permafrost-affected tundra is more complex and no studies of their influence on river runoff have been made so far for this region. In tundra, the fires take place only during exceptionally dry summers. They lead to an increase of thaw depth over frozen ground. Also, by burning the light-colored lichens, fires lead to a decrease in the surface albedo and thus increased heating. As a result, fires can lead to 1) a surplus of water released by the watershed but also to 2) the generation of small thermokarst hollows and ponds retaining the waters. Restoration of the natural conditions in the tundra can take up to 20 years (Walker 1999).

Our observations made during the Biogeochemical Cycle of Carbon in Wetlands of Western Siberia (CARWET-SIB) project field work in 2008 and 2010 in the region of Pangody (interfluve of the Pur and the Nadym Rivers, west of Urengoy city) showed that construction of roads and pipelines results in blocking of the lateral flow connection and in water accumulation and, thus, an increase of active layer depth along them. On the bog plateaus, the ancient dirt roads are now filled with water with clearly observed slow flow. The quantity of the drained lakes along the roads is much higher compared to the nondisturbed areas. Along the $100 \mathrm{~km}$ of road in the investigated area in the band of $\pm 6 \mathrm{~km}$, all forest has a trace of the recent or ancient (about 30 years) fires.

\section{Conclusions}

Snow cover plays a dominant role in the formation of the PNPT rivers discharge and its seasonal distribution. By analyzing various snow cover parameters from in situ data at the Tarko-Sale station we have provided an overview of the snow regime. By using passive microwave observations from SSM/I we may extend our assessment of the snow regime over the whole PNPT watershed.

The established regional relationship between in situ and satellite estimates of the snow cover parameters provide reliable estimates of the spatially distributed snow depth and, consequently, the snow water equivalent and, thus, the water stored as snow every winter. This approach makes it possible to quantitatively evaluate the role of the catchment's water storage and release in spring flood flow formation. We have established a regional relationship between adjusted SSM/I snow water equivalent and flood flow (correlation coefficient $R=0.70)$. 
By comparing the volume of water stored on the watersheds in winter to the spring meltwater flood flow volume we also observe that on average $30 \%$ (varying from $0 \%$ to $74 \%$ ) of meltwater does not reach the main rivers. The ratio of these water losses is increasing with time from $20 \%-30 \%$ in the early 1990 s to $50 \%-60 \%$ in the mid-2000s. These losses and their amplification can be attributed to several factors, such as evaporationsublimation of snow, evaporation of meltwater from the watershed, changes in surface properties related either to air temperature changes or human activity, and fires. Further research is needed to better assess and quantify the influence of these factors on the relationship between snow cover and spring flood flow generation on the PNPT watershed, especially in the context of the recent reduction of the Arctic snow cover extent (Brown et al. 2010).

Acknowledgments. The research has been supported by the Russian-French cooperation GDRI CAR-WETSIB "Biogeochemical Cycle of Carbon in Wetlands of Western Siberia," by the French ANR "IMPACTBoreal" and "CLASSIQUE" projects, and by the EU FP7 Project Monarch-A "Monitoring and Assessing Regional Climate Change in High Latitudes and the Arctic." The NSIDC is greatly thanked for processing and freely distributing SSM/I data. We are also grateful for the Center for Topographic Studies of the Oceans and Hydrosphere (CTOH) at LEGOS, Toulouse, France for providing the radiometric data. GlobCover Data $(C$ ESA/ESA GlobCover Project, led by MEDIAS-France/ POSTEL. We thank Dr. Eylon Shamir (Hydrologic Research Center, San Diego, CA) and three anonymous reviewers for their helpful comments on the manuscript, and Prof. Nick Hall (LEGOS, Toulouse, France) for help with the manuscript revision.

\section{REFERENCES}

Akimenko, T. A., E. A. Zakharova, and A. V. Kouraev, 2001: Hydrology of the Ob' river system. INTAS Project 97-3127 working paper, $37 \mathrm{pp}$.

ArcticRIMS, cited 2009: ArcticRIMS-A regional, integrated hydrological monitoring system for the pan-Arctic land mass. [Available online at http://rims.unh.edu/index.shtml.]

Armstrong, R. L., K. W. Knowles, M. J. Brodzik, and M. A. Hardman, 2003: DMSP SSM/I Pathfinder Daily EASE-Grid Brightness Temperatures. National Snow and Ice Data Center, CD-ROM.

Benavides-Solorio, J., and L. H. MacDonald, 2001: Post-fire runoff and erosion from simulated rainfall on small plots, Colorado Front Range. Hydrol. Processes, 15, 2931-2952.

Berezovskaya, S., D. Yang, and D. Kane, 2004: Compatibility analysis of precipitation and runoff trends over the large Siberian watersheds. Geophys. Res. Lett., 31, L21502, doi:10.1029/ 2004 GL021277.
Biancamaria, S., N. M. Mognard, A. Boone, M. Grippa, and E. G. Josberger, 2008: A satellite snow depth multi-year average derived from SSM/I for the high latitude regions. Remote Sens. Environ., 112, 2557-2568.

Boone, A., N. M. Mognard, B. Decharme, H. Douville, M. Grippa, and K. Kerrigan, 2006: The impact of simulated soil temperatures on the estimation of snow depth over Siberia from SSM/I compared to a multi-model climatology. Remote Sens. Environ., 101, 482-494.

Bowling, L. C., and D. P. Lettenmaier, 2010: Modeling the effects of lakes and wetlands on the water balance of arctic environments. J. Hydrometeor., 11, 276-295.

Brown, R., C. Derksen, and L. Wang, 2010: A multi-data set analysis of variability and change in Arctic spring snow cover extent, 1967-2008. J. Geophys. Res., 115, D16111, doi:10.1029/ 2010JD013975.

Burakov, D. A., 1978: Osnovy gidrologicheskih prognozov obyema i maksimuma vesennego polovodya v lesnoy zone ZapadnoSibirskoy ravniny (Base for hydrological forecasts of volume and maximal values of the spring flood in the forest zone of the Western Siberian plain). Vopr. Geogr. Sib., 11, $3-55$.

Decharme, B., H. Douville, C. Prigent, F. Papa, and F. Aires, 2008: A new river flooding scheme for global climate applications: Off-line evaluation over South America. J. Geophys. Res., 113, D11110, doi:10.1029/2007JD009376.

— R. Alkama, F. Papa, S. Faroux, H. Douville, and C. Prigent, 2011: Global off-line evaluation of the ISBA-TRIP flood model. Climate Dyn., doi:10.1007/s00382-011-1054-9, in press.

Déry, S. J., K. Stahl, R. D. Moore, P. H. Whitfield, B. Menounos, and J. E. Burford, 2009: Detection of runoff timing changes in pluvial, nival, and glacial rivers of western Canada. Water Resour. Res., 45, W04426, doi:10.1029/2008WR006975.

Ershov, E. D., Ed., 1989: Geocryology of the USSR: Western Siberia. Nedra, 454 pp.

Grippa, M., N. Mognard, T. Le Toan, and E. G. Josberger, 2004: Siberia snow depth climatology derived from SSM/I data using a combined dynamic and static algorithm. Remote Sens. Environ., 93, 30-41.

,-- , and -2005 : Comparison between the interannual variability of snow parameters derived from SSM/I and the $\mathrm{Ob}$ river discharge. Remote Sens. Environ., 98, 35-44.

,$--\longrightarrow$, , and S. Biancamaria, 2007: Observations of changes in surface water over the western Siberia lowland. Geophys. Res. Lett., 34, L15403, doi:10.1029/2007GL030165.

Ivanov, E. K., and S. M. Novikov, Eds., 1976: Bogs of Western Siberia-Their Structure and Hydrological Regime (in Russian). Hydrometeoizdat, 448 pp.

Kalnay, E., and Coauthors, 1996: The NCEP/NCAR 40-Year Reanalysis Project. Bull. Amer. Meteor. Soc., 77, 437-471.

Kirpotin, S., Yu. Polishchuk, E. Zakharova, L. Shirokova, O. Pokrovsky, M. Kolmakova, and B. Dupre, 2008: One of the possible mechanisms of thermokarst lakes drainage in WestSiberian North. Int. J. Environ. Stud., 65, 631-635.

_ , and Coauthors, 2009: Western Siberia wetlands as indicator and regulator of climate change on the global scale. Int. J. Environ. Stud., 66, 409-421.

Kondratyev, K. A., and V. A. Kudryavtsev, 1981: Map of geocryological regioning of USSR. Merzlotovedeniye, V. A. Kudryavtsev, Ed., Moscow State University Publishing, 240 pp.

Kotlyakov, V. M., Ed., 1997: Atlas Snezhno-Ledovykh Resursov Mira (World Atlas of Snow and Ice Resources). Moscow Russian Academy of Sciences, Institute of Geography, 264 pp. 
Krenke, A., 2004: Former Soviet Union hydrological snow surveys, 1966-1996. National Snow and Ice Data Center, Boulder, CO, digital media. [Available online at http://nsidc.org/data/g01170. html.]

Maidment, D. R., Ed., 1993: Handbook of Hydrology. McGrawHill, 1400 pp.

McNamara, J. P., D. L. Kane, and L. D. Hinzman, 1997: Hydrograph separations in an Arctic watershed using mixing model and graphical techniques. Water Resour. Res., 33, $1707-1719$.

Mognard, N. M., and E. G. Josberger, 2002: Northern Great Plains 1996/97 seasonal evolution of snowpack parameters from satellite passive microwave measurements. Ann. Glaciol., 34, 15-23.

Moskvin, Yu. P., 1989: Runoff from the rised bogs in Western Siberia. Russ. Meteor. Hydrol., 3, 88-94.

Novikov, S. M., 1988: Problemy gidrologicheskogo izucheniya zabolochennyh territoriy Zapadnoy Sibiri v svyazi s ih hozyaystvennym osvoeniyem (Problems of hydrological studies of the bogged regions of Western Siberia in view of its economical development). Russ. Meteor. Hydrol., 11, 108-118.

Papa, F., C. Prigent, and W. B. Rossow, 2007: Ob' River inundations from satellite observations: A relationship with winter snow parameters and river runoff. J. Geophys. Res., 112, D18103, doi:10.1029/2007JD008451.

Sheffield, J., G. Goteti, and E. F. Wood, 2006: Development of a 50year high-resolution global dataset of meteorological forcings for land surface modeling. J. Climate, 19, 3088-3111.

Shiklomanov, A. I., R. B. Lammers, and C. J. Vorosmarty, 2002: Widespread decline in hydrological monitoring threatens PanArctic research. Eos, Trans. Amer. Geophys. Union, 83, 13, doi:10.1029/2002EO000007.
Smith, L. C., Y. Sheng, G. M. McDonald, and L. D. Hinzman, 2005: Disappearing Arctic lakes. Science, 308, 1429, doi:10.1126/ science. 1108142.

Sokolov, A. A., 1952: Gidrografiya SSSR (Hydrography of the USSR). Gidrometizdat, $287 \mathrm{pp}$.

Sokolovskiy, D., 1968: River Runoff: Theory and Calculation Methods. Hydrometeoizdat, 539 pp.

Vodogretskiy, V. E., Ed., 1973: Altay and Western Siberia. Vol. 15. Hydrometeoizdat, $423 \mathrm{pp}$.

Walker, L. R., Ed., 1999: Ecosystems of Disturbed Ground. Elsevier Science, $868 \mathrm{pp}$.

Woo, M.-K., D. L. Kane, S. K. Carey, and D. Yang, 2008: Progress in permafrost hydrology in the new millennium. Permafrost Periglacial Processes, 19, 237-254, doi:10.1002/ppp.613.

Yang, D., D. Robinson, Y. Zhao, T. Estilow, and B. Ye, 2003: Streamflow response to seasonal snow cover extent changes in large Siberian watersheds. J. Geophys. Res., 108, 4578, doi:10.1029/2002JD003149.

Ye, H., D. Yang, T. Zhang, X. Zhang, S. Ladochy, and M. Ellison, 2004: The impact of climatic conditions on seasonal river discharges in Siberia. J. Hydrometeor., 5, 286-295.

Zakharova, E. A., A. V. Kouraev, M. V. Kolmakova, N. M. Mognard, V. A. Zemtsov, and S. N. Kirpotin, 2009a: The modern hydrological regime of the northern part of Western Siberia from in situ and satellite observations. Int. J. Environ. Stud., 66, 447-463.

,,,$----\frac{-}{-}$, and $-2009 \mathrm{~b}$ : Freshwater input to the Ob' estuary and modern hydrological regime of the northern part of western Siberia. Proc. Fourth Workshop on Remote Sensing of the Coastal Zone, Crete, Greece, EARSeL, 29.

Zhang, Y., W. Chen, and J. Cihlar, 2003: A process-based model for quantifying the impact of climate change on permafrost thermal regimes. J. Geophys. Res., 108, 4695, doi:10.1029/ 2002JD003354. 